\title{
Factor V G1691A (Leiden) is a major etiological factor in Egyptian Budd-Chiari syndrome patients
}

\author{
Mısır'l Budd-Chiari sendromlu hastalarda Faktör G1691A Leiden \\ major bir etyolojik faktördür
}

\author{
Tawhida Y. Abdel Ghaffar1,2, Solaf M. Elsayed 1,2,3, Mohamed A. Sakr4, \\ Ezzat S. Elsobky ${ }^{2,3}$, Sara M. Abdelhakam ${ }^{4}$, Said Yousuf5, Yonca Eğinn', Nejat Akar6 \\ 'Yassin Abdelghaffar Charity Center for Liver Disease and Research, Cairo, Egypt \\ 2 Ain Shams University, Children's Hospital, Cairo, Egypt \\ ${ }^{3}$ Department of Medical Genetics Center Ain Shams University, Cairo, Egypt \\ ${ }^{4}$ Department of Tropical Medicine, Ain Shams University, Cairo, Egypt \\ ${ }^{5}$ Department of Hematology, Ain Shams University, Cairo, Egypt \\ ${ }^{6}$ Department of Pediatric Molecular Genetics, Faculty of Medicine, Ankara University, Ankara, Turkey
}

\begin{abstract}
Objective: Budd-Chiari syndrome is a multifactorial disease in which several prothrombotic disorders may predispose patients to the development of thrombosis at this uncommon location (hepatic veins). The aim of this study was to determine the prevalence and characteristics of inherited thrombophilia in Egyptian Budd-Chiari syndrome patients.

Materials and Methods: The study included 47 Budd-Chiari syndrome patients (20 children and 27 adults). Genotyping of Factor V G1691A (Leiden), prothrombin G20210A (PT), and methylenetetrahydrofolate reductase C677T were performed using real-time PCR and fluorescence melting curve detection analysis.

Results: Factor V Leiden was observed in 29 patients (61.7\%). It is the only factor that caused BuddChiari syndrome in 18 of the patients and in 5 of the patients with inferior vena cava involvement. Myeloproliferative disease was noted in $12(25.5 \%)$ patients, antiphospholipid syndrome in 5 (10.6\%), and Behcet's disease in 3 (6.4\%). Interestingly, 3 of the children with Budd-Chiari syndrome had lipid storage disease.

Conclusion: Factor V Leiden was a major etiological factor in Egyptian Budd-Chiari syndrome patients, which may have been related to the high frequency of this mutation in the study region. Factor $\mathrm{V}$ Leiden was also a strong thrombophilic factor and the leading cause of inferior vena cava thrombosis in these patients. Lipid storage disease should be included as a risk factor for Budd-Chiari syndrome. (Turk J Hematol 2011; 28: 299-305)

Key words: Budd-Chiari syndrome, thrombophilia, Factor V Leiden, prothrombin, methylenetetrahydrofolate, Niemann-Pick, Gaucher, Behcet's syndrome, thrombosis
\end{abstract}

Received: January 13, 2011

Accepted: May 20, 2011

Address for Correspondence: Assoc. Prof. Solaf M. Elsayed, Medical Genetics Center, 27A Baghdad Street, Korba, 11341 Cairo, Egypt Phone: +202 24151999 E-mail: elsayed683@yahoo.com

doi:10.5152/tjh.2011.84 
Özet

\begin{abstract}
Amaç: Budd-Chiari sendromunun etyolojisinde çok farklı nedenler rol oynayabilir. Farklı protrombotik bozukluklar, bu sendromun oluşmasına yol açabilir. Bu çalışmada Mısır'lı Budd Chiari Sendromu tanısı almış hastalarda trombofilik nedenlerin sıklığıyla hastaların özelliklerinin karşılaştırılması amaçlanmiştır.

Yöntemler ve Gereçler: Çalışmaya 20 çocuk ve 27 erişkin olmak üzere 47 hasta dahil edilmiştir. Faktör V Leiden G1691A, Prothrombin G20210A and methylenetetrahydrofolate reductase C677T genotiplemeleri gerçek zamanlı polimeraz zincir reaksiyon (PZR) yöntemi kullanılarak gerçekleștirilmiştir. FV Leiden toplam 29 hastada (\%61.7) saptanmış olup, daha once yapılan çalışmalara göre yüksek bir orandır. 18 hastada Budd Chiari sendromu oluşması için tek etyolojik neden olarak göze çarpmaktadır. Myeloproliferatif hastalık sadece 12 (\%25.5), antifosfolipid sendromu 5 (\%10.6), ve Behçet hastalığı 3 (\%6.4) hastada saptanmıştır. İlginç olan 3 çocukta lipid depo hastalıkların da belirlenmiş olmasıdır. Sonuç: Faktör V Leiden'ın Budd Chiarinin oluşmasındaki temel etyolojik faktörlerden biri olarak göze çarpmaktadır. Bu ise mutasyonun Misır toplumunda yüksek oranda bulunmasına bağlanabilir. Lipid depo hastalıklarının da Budd Chiari için risk faktörü olarak dahil edilmesi gerekmektedir.

(Turk J Hematol 2011; 28: 299-305)

Anahtar kelimeler: Budd- Chiari sendromu, thrombofili, Factor V Leiden, prothrombin, methylenetetrahydrofolate, Niemann-Pick, gaucher, Behçet sendromu, thromboz
\end{abstract}

\section{Introduction}

Budd-Chiari syndrome (BCS) is characterized by obstruction of the hepatic venous outflow tract in the absence of right-sided heart failure and constrictive pericarditis [1]. Clinical manifestations include abdominal pain, ascites, and liver and spleen enlargement, as well as dilatation of the subcutaneous veins of the trunk in patients with longstanding inferior vena cava (IVC) obstruction [2].

Primary BCS is a multifactorial disease in which several prothrombotic disorders may predispose patients to the development of thrombosis at this uncommon location (hepatic veins) [3]. The prevalence and cause of BCS vary by geographic region $[3,4]$. Thromboses are prominent etiological factor in the West, while webs are more common etiology in the East and in Japan [5,6]. In Turkey, Behcet's disease and hydatid disease are more common etiologies [7]. Inherited thrombophilia was reported to be a major risk factor in $31 \%$ of BCS patients [8]. Factor V G1691A (Leiden) (FVL) is considered the most common inherited risk factor [9] and the second most frequent etiologic factor (following polycythemia vera [PV]) for BCS [10]. The frequency of prothrombin (PT) G20210A mutation igreater in southern Europe than in northern Europe, and is rare in the Middle East and Africa [11]. Hyperhomocysteinemia and homozygous methylenetetrahydrofolate reductase MTHFR C677T mutation were reported to be important risk factors for BCS [12].
To the best of our knowledge the prevalence and effects of these factors in Egyptian BCS patients have not been reported, and few data exist on children with BCS. The aim of the present study was to determine the prevalence and characteristics of inherited thrombophilia in both pediatric and adult Egyptian BCS patients.

\section{Materials and Methods}

The study included 47 consecutive patients (23 male and 24 female) diagnosed as BCS between January 2008 and January 2010 at Ain Shams University, Tropical Medicine Clinic, and Yassin Abdel Ghaffar Charity Center for Liver Disease and Research, both of which are major tertiary referral centers. BCS was diagnosed based on partial or complete obstruction of hepatic outflow documented via appropriate abdominal radiographic imaging (diagnostic criteria). Patients with veno-occlusive disease and those with hepatic outflow obstruction caused by congestive heart failure were excluded (exclusion criteria) from participating in the study.

The 47 patients were divided into group 1 (children, $n=20$ ) and group 2 (adults, $n=27$ ). All the patients were treated by $\geq 1$ of the authors. The control group included 130 healthy adult and children Egyptian volunteers. Mean age of controls was 31.9 years (median: 29 years). Controls with a family history of thrombosis were excluded. Genotyping of FVL G1691A, prothrombin G20210A, and MTHFR 
C677T was performed in all the controls. The study protocol was approved by the ethical committee of both Yassin Abdelghaffar Charity Center for Liver Diseases and Research and Ain Shams University. An informed consent was obtained from the adult patients and controls, and from the parents of the pediatric patients. Medical history and family history of spontaneous deep venous thrombosis and acquired risk factors for BCS, such as use of oral contraceptive pills and pregnancy, were recorded for each patient.

Protein C, protein S, and antithrombin III levels, lupus anticoagulant, and anticardiolipin antibodies were measured in all the patients for detection of antiphospholipid syndrome (APL). Patients with heterozygous JAK2 V617F mutation were diagnosed as myeloproliferative disease (MPD). Diagnosis of Niemann-Pick disease (NPD) was based on low acid sphingomyelinase activity ( $<5 \%$ of normal) in isolated leukocytes and Gaucher disease (GD) was diagnosed based on low $\beta$ - glucocerebrosidase activity ( $<5 \%$ of normal) in isolated leukocytes.

DNA was isolated using a Magna Pure Automatic Isolation System (Roche Diagnostics, Indianapolis, USA). Genotyping of FVL G1691A, prothrombin G20210A, and MTHFR C677 was performed via realtime PCR and fluorescence melting curve detection analysis using a Light Cycler System (Roche Diagnostics, Manheim, Germany); primers were obtained from TIB MOLBION (Berlin, Germany).

\section{Statistical methods}

SPSS for Windows v.13.0 (SPSS Inc, USA) was used for data entry and analysis. All numeric variables are expressed as mean \pm standard deviation (SD). Comparison of variables between groups was performed using Student's t test and the MannWhitney U test was used for normal and nonparametric variables. The chi-square $\left(\chi^{2}\right)$ test was used to compare the frequency of qualitative variables between groups. Spearman's correlation test was used to determine the correlation between nonparametric variables. For all tests a $\mathrm{p}$ value $<0.05$ was considered statistically significant [13].

\section{Results}

Patient characteristics are shown in Table 1. Ascites was significantly more common in the adult patients, whereas dilated abdominal veins were significantly more common in the pediatric patients. Medical history and family history of spontaneous deep venous thrombosis were negative in all the patients. BCS was not associated with pregnancy or use of oral contraceptive pills in any of the adult female patients. Inherited thrombophilia mutations (FVL and PT) were noted in $30(63.8 \%)$ patients (29 with FVL and 1 with PT). The frequency of FVL was significantly higher in the BCS patients (no significant difference between pediatric and adult patients) than in the controls (Table 2). Furthermore, FVL was the only etiological factor for BCS in 18 of the patients (Table 3). None of the patients had protein $\mathrm{C}$, protein $\mathrm{S}$, or antithrombin III deficiency. All patients with MPD had heterozygous JAK2 V617F mutation.

Comparison of the patients with and without inherited thrombophilia mutations showed that dilated abdominal veins, ascites, and encephalopathy were more common in the patients with mutations, whereas jaundice was more common in those without mutations, although the differences were not statistically significant. Hepatic vein thrombosis was observed in 33 patients (70.2\%), IVC thrombosis was observed in only 3 patients (6.4\%), and both were observed in 11 patients (23.4\%). IVC involvement was observed in 14 patients $(29.8 \%), 45 \%$ of which were children (9/20); FVL mutation was noted in $50 \%$ of these 14 patients $(n=7)$ (Table 4$)$.

\section{Discussion}

The present study shows that FVL was a major etiological factor for thrombosis in Egyptian BCS patients; $61.7 \%$ of patients in the present study had FVL, as compared to previous reports of $26 \%-36 \%$ on different poulations $[1,14]$. This might have been due the high frequency of FVL in the study region [15]. In Egyptian children, FVL was previously reported to be the most common factor in Egyptian children with portal vein thrombosis, although to a lesser extent (30\%) [16]. This may be explained to the difference in the site of thrombosis (hepatic veins versus portal veins). In the present study, FVL alone (without other acquired factors) caused BCS in 18 of the patients and in $50 \%$ of patients with IVC involvement (as not all patients with BCS have IVC involvement), which contradicts the notion that is a relatively weak thrombotic factor and the assump- 
Table 1. Patient Characteristics

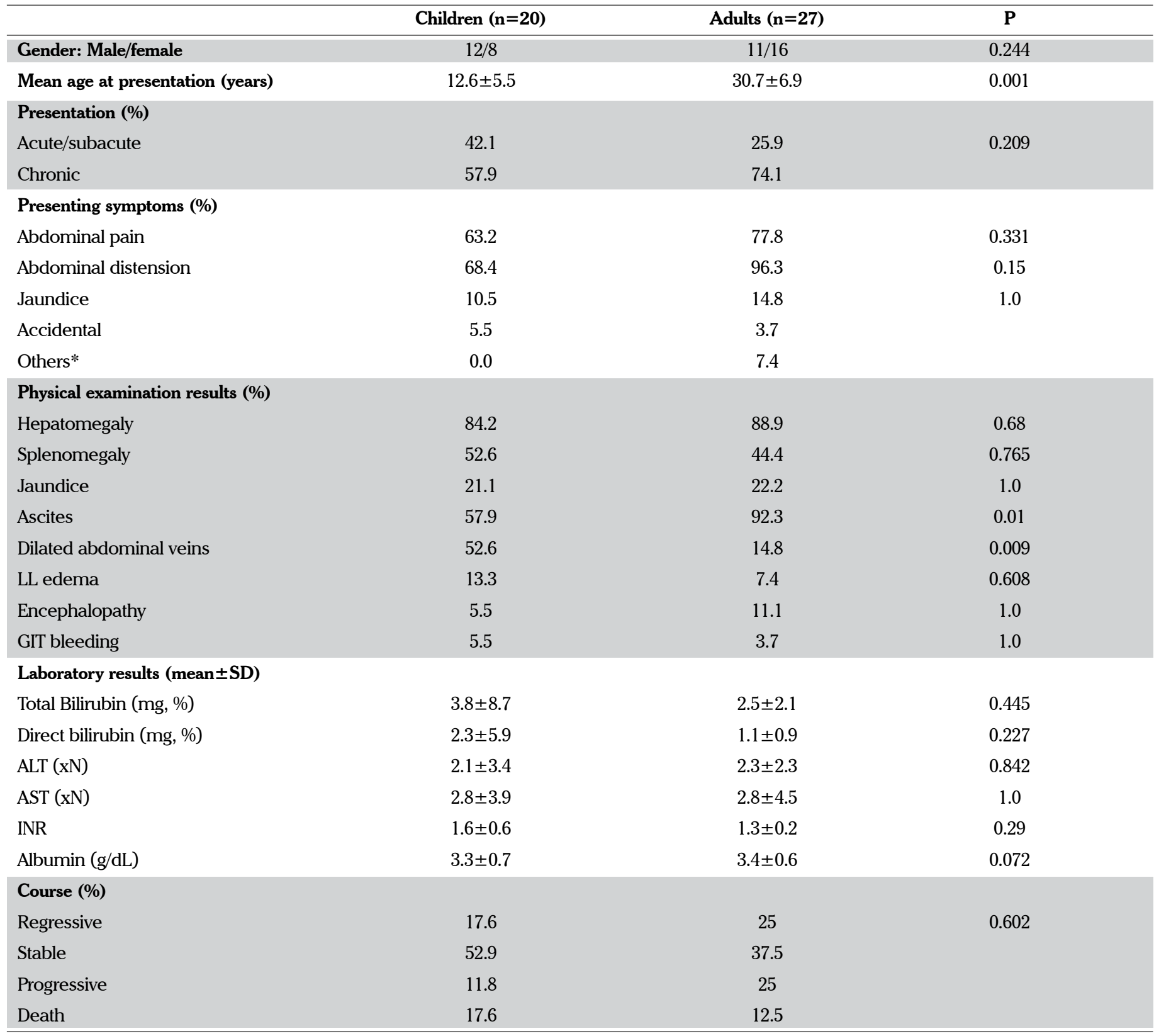

*Others: GIT bleeding, LL edema, xN: multiple of normal

tion that other essential factors must be present to cause thrombosis.

Another interesting finding of the present study is that 3 of the BCS patients had lipid storage disease (2 patients had GD and 1 had NPD), of which only one with GD had FVL. There is only one report of BCS in Gaucher disease patients [17] and no report of BCS in NPD patients. A possible explanation of hepatic vein obstruction in these patients is arterial thickening or narrowing secondary to swelling of the medial and intimal smooth-muscle cells which is supported by the autopsy findings in these patients [18].
On the other hand, in this study, only 1 patient had PT mutation, which is in agreement with previous reports indicating that this mutation is not a prominent etiological factor in BCS patients [1,19].

In the present study MTHFR C677T occurred more frequently in the adult patients than both children and controls, whereas homozygosity of this mutation occurred less frequently in the adult patients than in the controls, which indicates that it is not a strong thrombotic factor unless augmented by another acquired or hereditary risk factor. JAK2 V617F mutation-positive MPD was observed in only 
Table 2. Distribution of FVL, PT, and MTHFR Gene Mutations

\begin{tabular}{lcccccc} 
& $\mathbf{n}$ & & FVL & PT & \multicolumn{2}{c}{ MTHFR } \\
& & G/A (\%) & A/A (\%) & G/A (\%) & C/T (\%) & T/T (\%) \\
\hline Children & 20 & $10(50)$ & $3(15)$ & $0(0)$ & $6(30)$ & $1(5)$ \\
Adults & 27 & $14(51.9)$ & $2(7.4)$ & $1(3.7)$ & $13(48.1)$ & $1(3.7)$ \\
Controls* & 130 & $18(13.8)$ & $0(0)$ & $0(0)$ & $23(25.5)$ & $7(7.8)$ \\
\hline
\end{tabular}

*MTHFR was done to only 90 controls

Table 3. The Prevalence of Major Risk Factors in the BCS Patients

\begin{tabular}{|c|c|c|c|c|}
\hline Risk factor & & $\begin{array}{l}\text { Children } \\
\text { (n) }\end{array}$ & $\begin{array}{l}\text { Adults } \\
\text { (n) }\end{array}$ & $\begin{array}{l}\text { Total } \\
(\%)\end{array}$ \\
\hline \multirow[t]{2}{*}{ FVL } & Alone & 10 & 8 & $18(38.3)$ \\
\hline & With other risk factors & 3 & 8 & $11(23.4)$ \\
\hline PT mutation & Alone & 0 & 1 & $1(2.1)$ \\
\hline \multirow[t]{2}{*}{ MPD } & Alone & 1 & 6 & 7 (14.9) \\
\hline & With FVL & 1 & 4 & $5(10.6)$ \\
\hline APL & With FVL & 1 & 3 & $4(8.5)$ \\
\hline \multirow[t]{2}{*}{ Behcet disease } & Alone & 1 & 1 & $2(4.2)$ \\
\hline & With FVL & 0 & 1 & $1(2.1)$ \\
\hline Lipid storage disease & Alone & 2 & 0 & $2(4.2)$ \\
\hline
\end{tabular}

APS: Antiphospholipid syndrome; FVL: factor V Leiden; MPD: myeloproliferative disease; NP: Niemann-Pick disease

Table 4. The Prevalence of Major Risk Factors in the BCS Patients with IVC İnvolvement

\begin{tabular}{llll}
\hline & & n & Total(\%) \\
\hline FVL & Alone & 5 & $5(35.7)$ \\
& With other risk factors & 2 & $2(14.3)$ \\
MPD & Alone & 2 & $2(14.3)$ \\
APL & Alone & 1 & $2(14.3)$ \\
& With FVL & 1 & \\
Behcet disease & Alone & 1 & $2(14.3)$ \\
& With FVL & 1 & \\
NPD & Alone & 1 & $1(7.1)$ \\
No apparent factor & 2 & $2(14.3)$ \\
\hline
\end{tabular}

APS: Antiphospholipid syndrome; FVL: factor V Leiden; MPD: myeloproliferative disease; NP: Niemann-Pick disease

$25.5 \%$ of the present study's patients, which is a lower frequency than previously reported in BCS [20,21]. Acquired factors, including Behcet's disease, were noted in $7.4 \%$ of the presented adult patients, which is similar to the frequency reported in Turkey (9\%) [7], a country which has a long historical background with Egypt; among these patients, 1 had pure involvement of the hepatic veins without IVC involvement, which is a rare finding [22].
In the present study the male to female patient ratio was close to one (1.04:1); which is consistent with that reported by the European Network for Vascular Disorders of the Liver [23].

In conclusion, FVL (independently causing hypercoagulopathy or as a cofactor in different disease states) was a prominent etiological factor for BCS in our Egyptian patient population, most likely due to the prevalence of this mutation in the study region [15]. It was a strong thrombophilic factor and the leading cause of IVC thrombosis in the presented BCS patients, which is in contrast with PT and MTHFR, both of which had little effect on thrombosis in the BCS patients. Lipid storage disease may be considered a risk factor for BCS. Appropriate risk assessment should include complete thrombophilia screening in patients with BCS, even in the presence of overt acquired thrombotic risk factors.

\section{Author Contributions}

TYA: Diagnosis and follow-up of the pediatric BCS patients, writing the manuscript, and interpretation of data. 
SME: Diagnosis and follow-up of the pediatric BCS patients, writing the manuscript, and interpretation of data.

MAS: Diagnosis and follow-up of the adult BCS patients, and writing the manuscript.

ESE: Interpretation of genetic test results and writing the manuscript.

SMA: Diagnosis and follow-up of the adults BCS patients.

SY: Diagnosis and follow-up of the adult patients with BCS, especially those with MPD.

YE: Molecular analysis.

NA: Molecular analysis, interpretation of the results, and writing the manuscript.

\section{Conflict of Interest Statement}

None of the authors of this paper has a conflict of interest, including specific financial interests, relationships, and/or affiliations relevant to the subject matter or materials included.

\section{References}

1. Janssen HL, Garcia-Pagan JC, Elias E, Mentha G, Hadengue A, Valla DC, European Group for the Study of Vascular Disorders of the Liver. Budd-Chiari syndrome: a review by an expert panel. J Hepatol 2003;38:364-71. [CrossRef]

2. Dilawari JB, Bambery P, Chawla Y, Kaur U, Bhusnurmath SR, Malhotra HS, Sood GK, Mitra SK, Khanna SK, Walia BS. Hepatic outflow obstruction (Budd-Chiari syndrome). Experience with 177 patients and a review of the literature. Medicine (Baltimore) 1994;73:21-36. [CrossRef]

3. Janssen HL, Meinardi JR, Vleggaar FP, van Uum SH, Haagsma EB, van Der Meer FJ, van Hattum J, Chamuleau RA, Adang RP, Vandenbroucke JP, van Hoek B, Rosendaal FR. Factor $\mathrm{V}$ Leiden mutation, prothrombin gene mutation, and deficiencies in coagulation inhibitors associated with Budd-Chiari syndrome and portal vein thrombosis: results of a case-control study. Blood 2000;96:2364-8.

4. Deltenre P, Denninger MH, Hillaire S, Guillin MC, Casadevall N, Briere J, Erlinger S, Valla DC. Factor V Leiden related Budd-Chiari syndrome. Gut 2001;48:264-8. [CrossRef]

5. Mohanty D, Shetty S, Ghosh K, Pawar A, Abraham P. Hereditary thrombophilia as a cause of Budd-Chiari syndrome: a study from Western India. Hepatology 2001;34:666-70. [CrossRef]

6. Okuda H, Yamagata H, Obata H, Iwata H, Sasaki R, Imai F, Okudaira M, Ohbu M, Okuda K. Epidemiological and clinical features of Budd-Chiari syndrome in Japan. J Hepatol 1995;22:1-9. [CrossRef]

7. Uskudar O, Akdogan M, Sasmaz N, Yilmaz S, Tola M, Sahin B. Etiology and portal vein thrombosis in Budd-
Chiari syndrome. World J Gastroenterol 2008;14:2858-62. [CrossRef]

8. Rajani R, Melin T, Björnsson E, Broomé U, Sangfelt P, Danielsson A, Gustavsson A, Grip O, Svensson H, Lööf L, Wallerstedt S, Almer SH. Budd-Chiari syndrome in Sweden: epidemiology, clinical characteristics and survival - an 18-year experience. Liver Int 2009;29:253-9. [CrossRef]

9. Mahmoud AEA, Elias E, Beauchamp N, Wilde JT. Prevalence of the factor $\mathrm{V}$ Leiden mutation in hepatic and portal vein thrombosis. Gut 1997;40:798-800. [CrossRef]

10. Minnema MC, Janssen HL, Niermeijer P, de Man RA. Budd-Chiari syndrome: combination of genetic defects and the use of oral contraceptives leading to hypercoagulability. J Hepatol 2000;33:509-12. [CrossRef]

11. Rosendaal FR, Doggen CJ, Zivelin A, Arruda VR, Aiach M, Siscovick DS, Hillarp A, Watzke HH, Bernardi F, Cumming AM, Preston FE, Reitsma PH. Geoegraphic distribution of the $20210 \mathrm{G}$ to A prothrombin variant. Thromb Haemost 1998;79:706-8.

12. Li X-M, Wei YF, Hao HL, He LS, Li JD, Mei B, Wang SY, Wang C, Wang JX, Zhu JZ, Liang JQ. Hyperhomocysteinemia and the MTHFR C677T mutation in Budd-Chiari syndrome. Am J Hematol 2002;71:11-4. [CrossRef]

13. Daniel WW. Biostatistics: A foundation for analysis in the health sciences, 6th edition. John Wiley and sons, Inc., New York, 1995.

14. Dutta AK, Chacko A, George B, Joseph JA, Nair SC, Mathews V. Risk factors of thrombosis in abdominal veins. World J Gastroenterol 2008;28:4518-22. [CrossRef]

15. Ulu A, Elsobky E, Elsayed M, Yıldız Z, Tekin M, Akar N. Frequency of five thrombophilic polymorphisms in the Egyptian population. Turk J Hematol 2006;23:100-3.

16. El-Karaksy H, El-Koofy N, El-Hawary M, Mostafa A, Aziz M, El-Shabrawi M, Mohsen NA, Kotb M, El-Raziky M, El-Sonoon MA, A-Kader $\mathrm{H}$. Prevalence of factor $\mathrm{V}$ Leiden mutation and other hereditary thrombophilic factors in Egyptian children with portal vein thrombosis: results of a single-center case-control study. Ann Hematol 2004;83:712-5. [CrossRef]

17. Haliloglu M, Hoffer FA, Haight AE, Cunningham JM. Budd-Chiari syndrome caused by Gaucher's disease. Pediatr Radiol 1999;29:908-10. [CrossRef]

18. Ishii H, Takahashi T, Toyono M, Tamura M, Harada K, Yoshida M, Nishikawa Y, Enomoto K, Takada G. Acid sphingomyelinase deficiency: cardiac dysfunction and characteristic findings of the coronary arteries. J Inherit Metab Dis 2006;29:232-4. [CrossRef]

19. Lin GL, Xu PQ, Qi H, Lian JH, Zheng H, Dang XW. Relations of Budd-Chiari syndrome to prothrombin gene mutation. Hepatobiliary Pancreat Dis Int 2004;3:214-8. 
20. Primignani M, Barosi G, Bergamaschi G, Gianelli U, Fabris F, Reati R, Dell'Era A, Bucciarelli P, Mannucci PM. Role of the JAK2 mutation in the diagnosis of chronic myeloproliferative disorders in splanchnic vein thrombosis. Hepatology 2006;44:1528-34. [CrossRef]

21. Patel RK, Lea NC, Heneghan MA, Westwood NB, Milojkovic D, Thanigaikumar M, Yallop D, Arya R, Pagliuca A, Gäken J, Wendon J, Heaton ND, Mufti GJ. Prevalence of the activating JAK2 tyrosine kinase mutation V617F in the Budd-Chiari syndrome. Gastroenterology 2006;130:2031-8. [CrossRef]
22. Bayraktar Y, Balkanci F, Bayraktar M, Calguneri M. BuddChiari syndrome: a common complication of Behcet's disease. Am J Gastroenterol 1997;92:858-62.

23. Darwish Murad S, Plessier A, Hernandez-Guerra M, Fabris F, Eapen CE, Bahr MJ, Trebicka J, Morard I, Lasser L, Heller J, Hadengue A, Langlet P, Miranda H, Primignani M, Elias E, Leebeek FW, Rosendaal FR, Garcia-Pagan JC, Valla DC, Janssen HL; EN-Vie (European Network for Vascular Disorders of the Liver). Etiology, management, and outcome of the Budd-Chiari syndrome. Ann Intern Med 2009;151:167-75. 